\title{
Sedimentology and palaeogeography of conglomerates from the Aghajari Formation in Zagros Basin, SW Iran
}

\author{
Mohammad Sahraeyan \\ Department of Geology, Khorasgan (Esfahan) Branch, Islamic Azad University, Esfahan, Iran \\ Corresponding authorE-mail:m.sahraeyan@yahoo.com
}

\begin{abstract}
Conglomerates, the lithified equivalent of gravels alternate with sandstones and mudstones in the upper parts of the Aghajari Formation in the Zagros Basin, southwestern Iran. The thickness of the Aghajari Formation in this studied area is 2221 meters. Polymictic conglomerates form excellent outcrops in the central parts of the study area. From the view of its (coarse) clast composition, the Aghajari Formation consists of two types of conglomerates: 1) limestone-chert clast-supported conglomerate (LCCSC) and 2) limestone clast-supported conglomerate (LCSC). The chronological and spatial relationships between these conglomerates are not easily determined caused by existence some thrust faults at their approximate boundaries. In the vertical succession, various lithofacies were recognized; their textural characteristics and sedimentary structures suggest a non-marine depositional system as they match with standard lithofacies of meandering rivers. Epirogenic movements in the region started in the Oligocene, showed by a polymictic conglomerate beds at the Jahrum-Asmari Formation boundary. These movements then changed to orogenic ones with the depositioning gravelly alluvium now known as Aghajari (upper parts) Formation.
\end{abstract}

Keywords: Aghajari Formation, lithofacies, meandering river, polymictic conglomerate, Zagros Basin.

\section{Introduction}

The Aghajari Formation, known as Upper Fars in the Zagros Basin in southwest of Iran and has a considerable importance in the stratigraphy of this zone. In order to present detailed information about this topic, one of the obvious outcrops of this formation in the southeast of Sarvestan was investigated, and thereby the palaeogeography of the region was determined. Analytical work on sedimentology shows that these coarse-grained clastic rocks were deposited as fluvial deposits by temporary or permanent rivers in response to uplift of the Zagros Mountain range in the Upper Miocene-Pliocene [1-10]. Tectonically the area is part of a foreland basin [5, 11] filled with a thick sequence of predominantly coarse clastic sedimentary rocks. Palaeoalluvial structures were examined in a wide range of tectonic settings, including foreland basins. Traditionally, the sediments of foreland basins, also the Aghajari Formation sediments, were considered as continental molasse [8-10, 12].

\section{Study area and methodology}

The study area (N: $\left.29^{\circ} 12^{\prime} 46^{\prime \prime} / \mathrm{E}: 53^{\circ} 21^{\prime} 04^{\prime \prime}\right)$ is found about $15 \mathrm{~km}$ northeast of Sarvestan in the Zagros Basin (Fig. 1A). Field work was concentrated at Mian Jangal Anticline and Imamzade Esmaeil Syncline in southeast of Sarvastan. A section was measured in detail crossing the trends of the anticline and syncline (Fig. 1B). Tectonically the area is part of a foreland basin filled dominantly with a thick sedimentary sequence of clastic compositions [4]. The total thickness of the Aghajari Formation in the study area is 2221 meters (Figs. 1B and 2). 


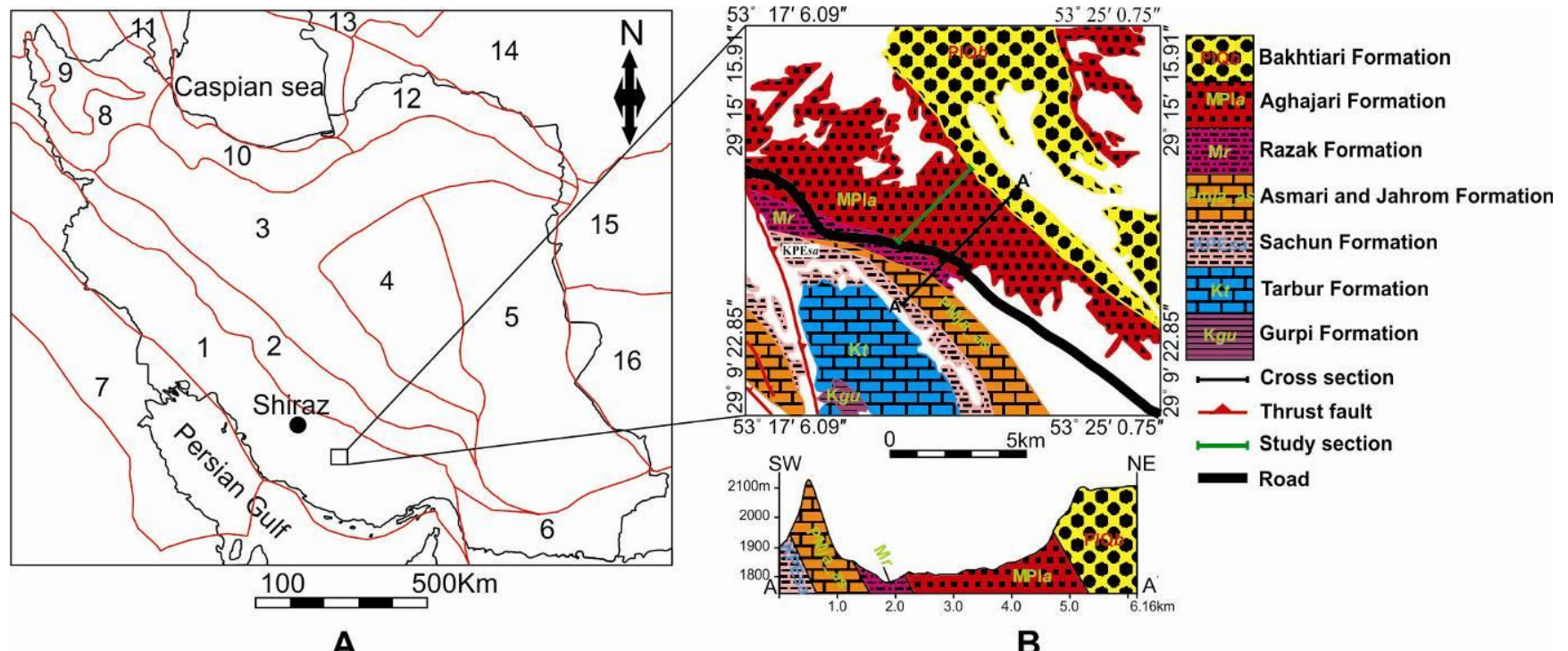

Fig. 1: A. General map of the states of Iran. The study area is in Folded Zagros Zone (after [13]), 1: Folded Zagros Zone; 2: Zagros Trust Zone; 3 : Central Iranian Basins; 4: Cen. Iranian Microcontinent; 5: Lut Block and Depression; 6: Makran; 7: Mesopotamian Foredeep Basin; 8: Lesser Caucasus; 9: Araks; 10: Alborz Fold Belt; 11: Kura Basin; 12: Kopet-Dag Fold Belt; 13: Karabugaz- Karakum High; 14: Amu-Darya Basin; 15: Central Afghanistan; 16: Baluchistan, B. Geological map of study area (after [14]).

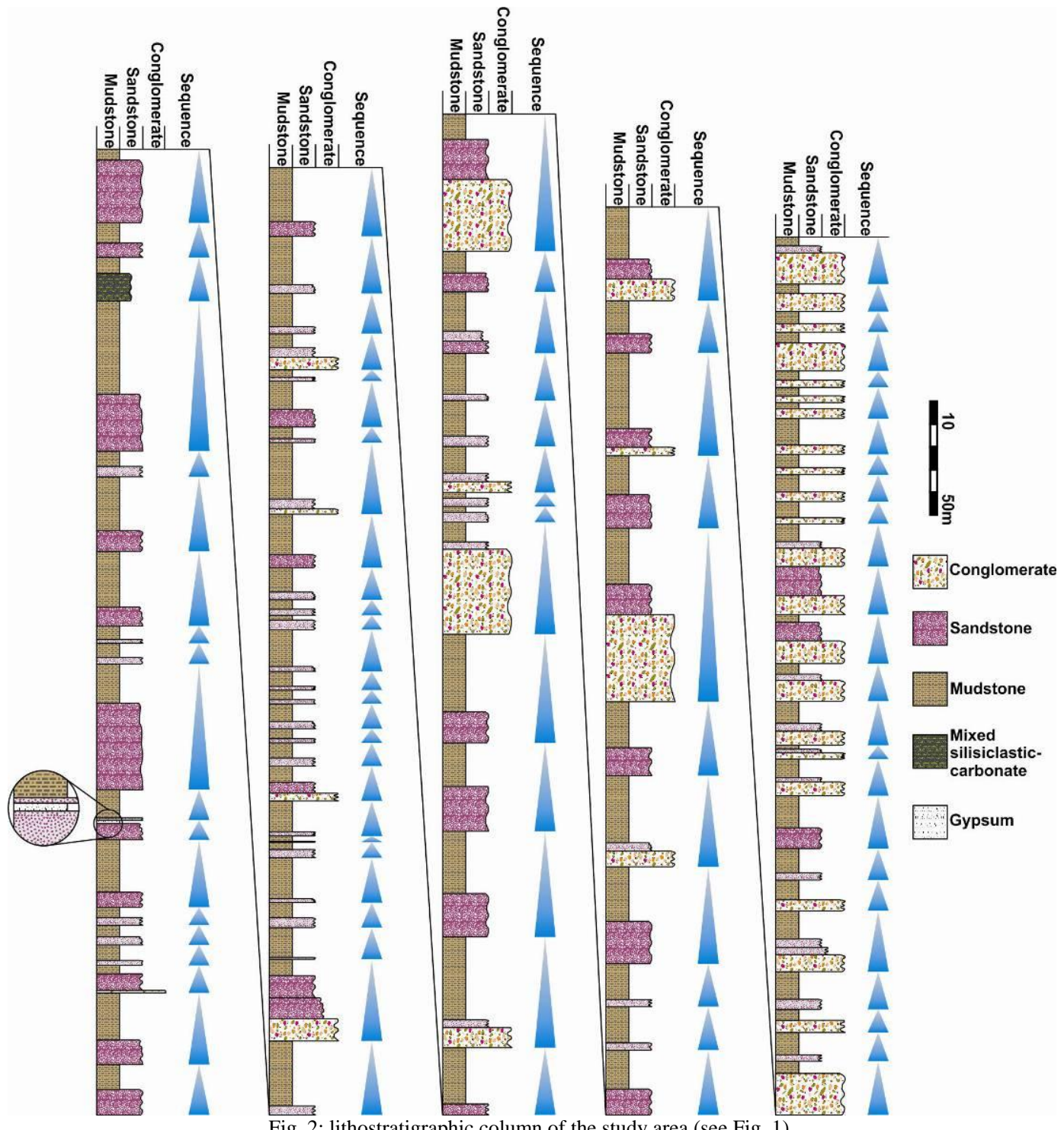

Fig. 2: lithostratigraphic column of the study area (see Fig. 1). 
The trend of Imamzade Esmaeil syncline is similar to the general Zagros trend (NW-SE). The dominant lithofacies of these successions from the top to the bottom are conglomerate, conglomerate-sandstone-mudstone, marl with lenses and interlayers of anhydrite and gypsum, and limestone-dolomitic limestone belonging to the Bakhtyari, Aghajari, Razak, and Jahrum-Asmari formations, respectively (Fig. 1B). In the study area, the lower contact with Razak Formation and the upper contact with Bakhtyari Formation are gradually (Fig. 3).
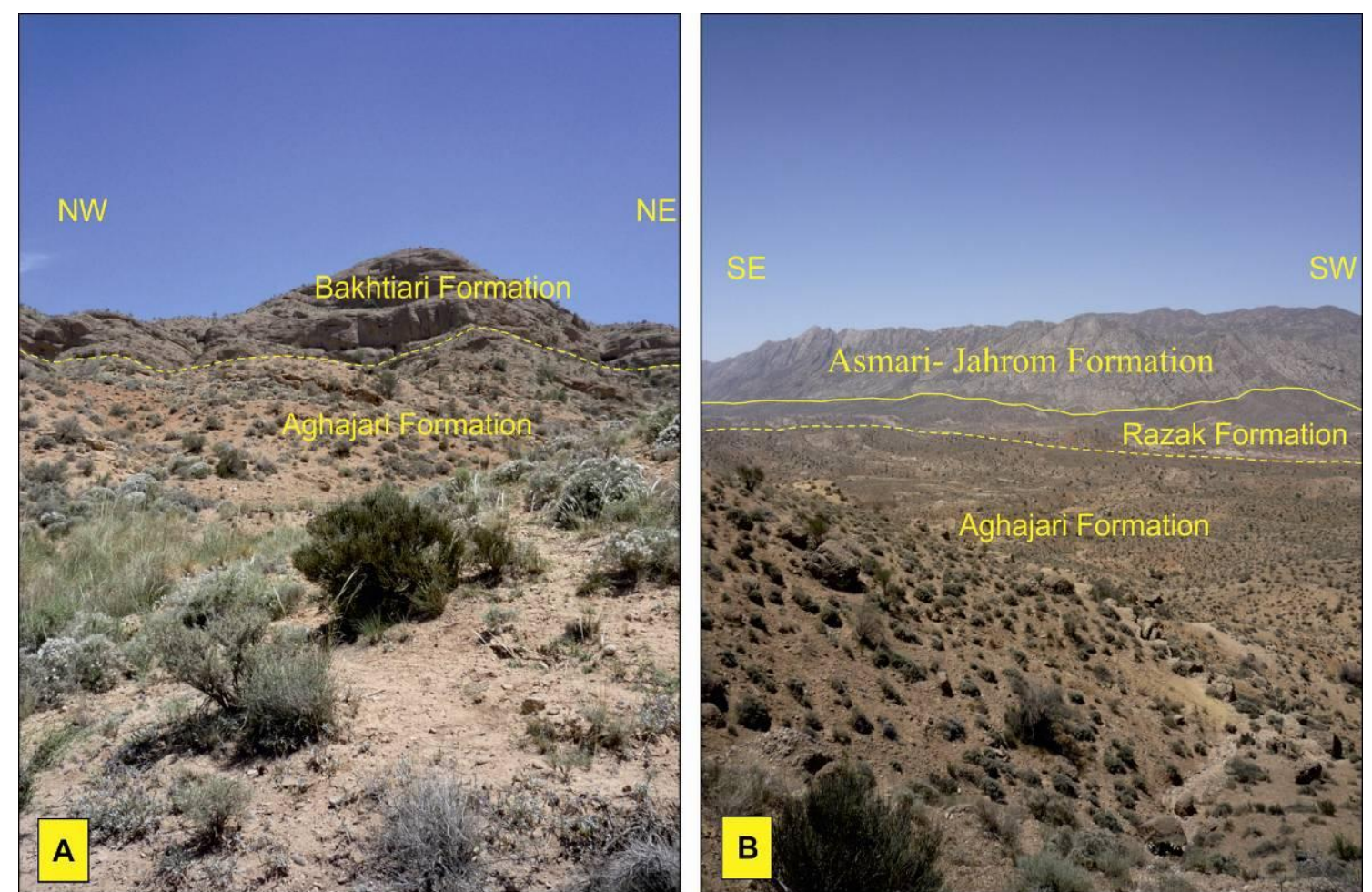

Fig. 3: A. Field photographs showing: A. Lower bounadry of Aghajari Formation with Razak Formation, which is gradual, and B. Upper boundary of Aghajari Formation with Bakhtiari Formation is also gradual.

Field work was carried out in the Imamzade Esmaeil Syncline. The following examinations were performed during this measurement: bed thickness, clast size and composition, matrix, sorting and other textural (i.e. imbrications and crossbedding) and structural features (i.e. load cast and ball and pillow structure).

\section{Lithofacies}

Epirogenic movement in the Paleogene caused some fluctuations in sea level, resulting in a bed of polymictic conglomerate at the Jahrum-Asmari Formation boundary (Fig. 4). Regression in the Burdigalian caused a series of continental environments (lacustrine, fluvial and alluvial fans) to occur. During this time, the basin received a large quantity of sediments from the neighboring newly uplifted highlands. The sediments accumulated into a vertical succession of thousands of meters thick. The upper part of this succession forms the Bakhtyari Formation, characterized by a series of standard lithofacies of braided rivers and alluvial fans [15].

Thus, conglomerates entered the succession as coarse clastic sediment from the Oligocene (polymictic conglomerate at the Jahrum-Asmari Formation boundary) by flow regime. In the Lower Miocene Razak Formation (in Internal Fars), there are thin interlayers of conglomerate in sandstone. The gradual appearance of conglomerate (alternating with sandstone and mudstone) started in the upper parts of the Aghajari Formation and gradually extended laterally and vertically, finally forming the nearly unique facies of the Bakhtyari Formation.

The conglomerates of Aghajari Formation consist of chert, limestone, and sandstones fragments (Table 1). Two lithofacies were seen in the Aghajari Formation: limestone-chert clast-supported conglomerate (LCCSC) and limestone clast- supported conglomerates (LCSC). 


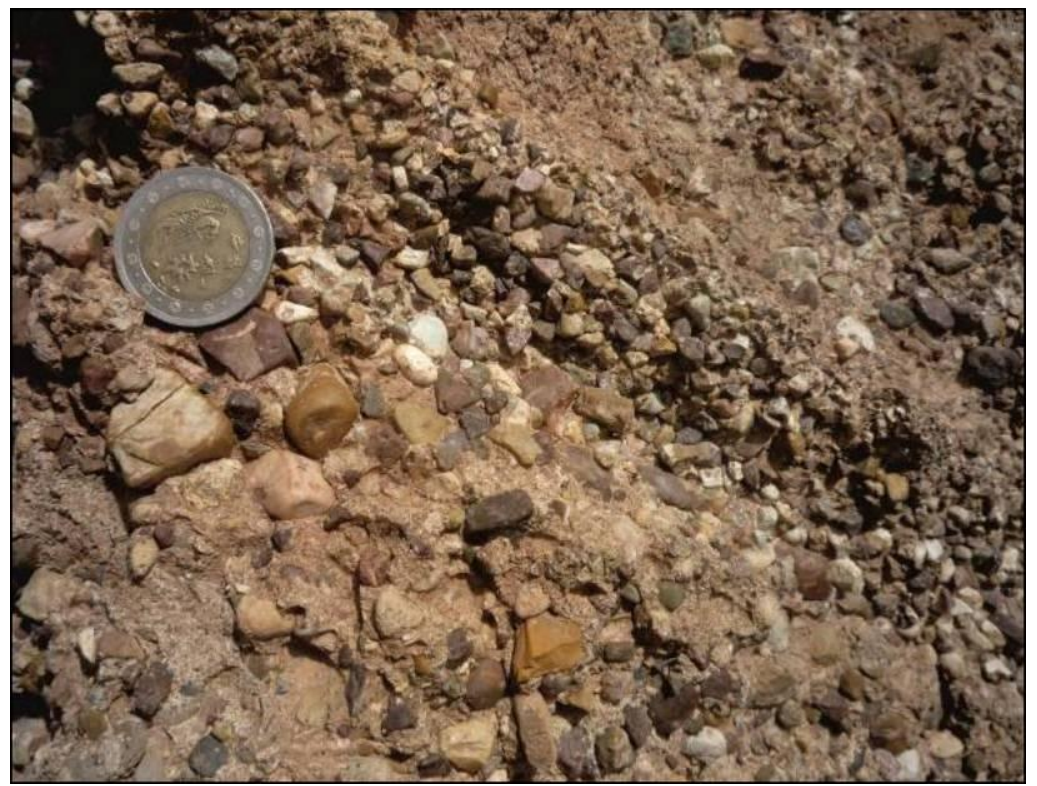

Fig. 4: Field photographs showing polymictic conglomerate at the Jahrum-Asmari Formation boundary.

\subsection{Limestone-chert clast-supported conglomerate (LCCSC)}

As mentioned above, the dominant clasts of these conglomerates are of chert and limestone. Whether the limestone or chert is dominant varies from section to section. Three different lithofacies are recognized:

\begin{tabular}{|c|c|c|c|c|c|c|c|}
\hline Thickness (m) & 570.9 & 695.45 & 762.15 & 883.1 & 1090.25 & 1123.55 & 1270.4 \\
\hline Chert (\%) & 93 & 92 & 92 & 94 & 92 & 87 & 89 \\
\hline Limestone (\%) & 5 & 5 & 4 & 4 & 5 & 10 & 9 \\
\hline Sandstone (\%) & 2 & 3 & 4 & 2 & 3 & 3 & 2 \\
\hline Thickness (m) & 1754.85 & 1775.8 & 1842.1 & 1853.5 & 1875.15 & 1897.95 & 1909.75 \\
\hline Chert (\%) & 82 & 75 & 70 & 68 & 68 & 67 & 60 \\
\hline Limestone (\%) & 13 & 20 & 22 & 22 & 22 & 20 & 28 \\
\hline Sandstone (\%) & 5 & 5 & 8 & 10 & 10 & 13 & 12 \\
\hline Thickness (m) & 1930.65 & 1944 & 1955.4 & 1966.1 & 1975.95 & 1992 & 1997.65 \\
\hline Chert (\%) & 59 & 45 & 43 & 42 & 41 & 40 & 38 \\
\hline Limestone (\%) & 28 & 38 & 40 & 47 & 48 & 49 & 49 \\
\hline Sandstone (\%) & 13 & 17 & 17 & 11 & 11 & 11 & 13 \\
\hline Thickness (m) & 2004.5 & 2020.9 & 2029.4 & 2042.75 & 2060.6 & 2096.25 & 2146.75 \\
\hline Chert (\%) & 36 & 18 & 20 & 21 & 23 & 20 & 17 \\
\hline Limestone (\%) & 54 & 75 & 72 & 72 & 65 & 78 & 69 \\
\hline Sandstone (\%) & 10 & 7 & 8 & 7 & 12 & 12 & 14 \\
\hline
\end{tabular}

\subsubsection{Conglomerate facies}

This facies was observed in lower part of this section and divided into two subfacies: (a) boulder-cobble conglomerate, and (b) pebble- granule conglomerate.

(a) Boulder-cobble conglomerate subfacies: In this subfacies, the dominant clasts are usually of limestone composition, although they may be nearly equal in quantity to chert clasts. Besides, limestone and chert clasts, which are the dominant facies, and framework of different sizes and amounts (Fig. 5). The mean and maximum sizes of limestone clasts are coarser than those of chert. The maximum clast size of the limestone is coarse boulders (sometimes 70 centimeters) and the mean size is cobbles. The maximum clast size of the chert grains is about the size of cobbles and the mean size is about the size of pebbles (Fig. 6). 


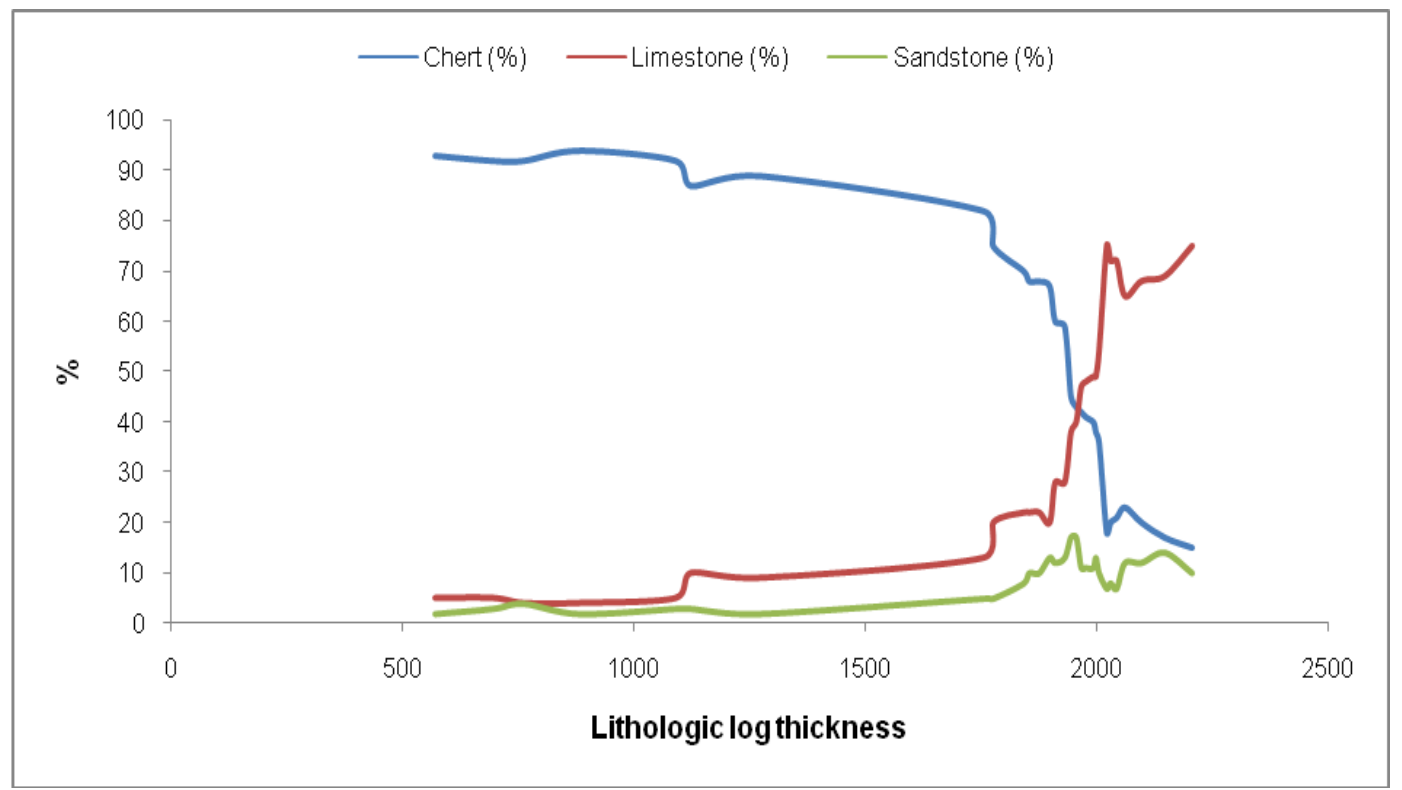

Fig. 5: Percentages of chert, limestone, and sandstone fragments in the conglomerates of Aghajari Formation compared with lithologic log thickness. The percentages of the limestone fragments are raise and percentages of the chert fragments are decrease while raising thickness of the lithologic log of Aghajari Formation.

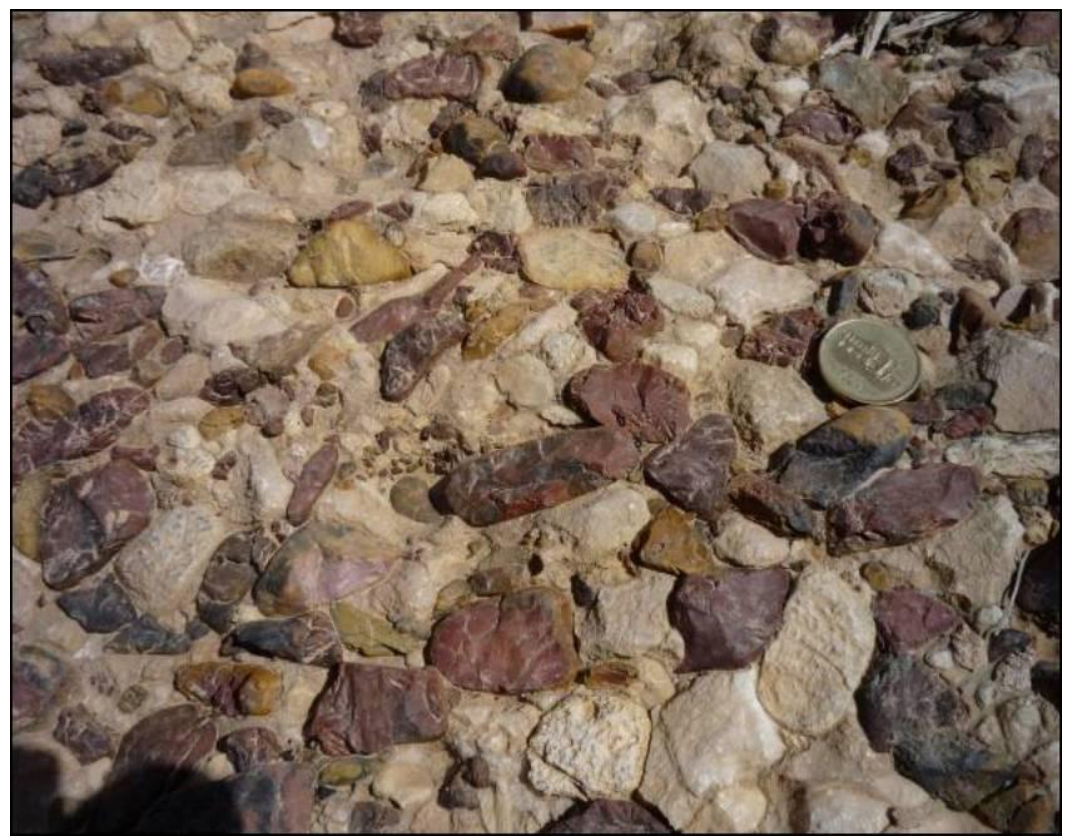

Fig. 6: Field photographs showing framework of chert fragments in the boulder-cobble conglomerate.

The maximum and mean sizes of the sandstone gravels and polymictic conglomerate clasts are boulders and cobbles, respectively. Because of the coarse-grained size, beds are commonly medium to massive. In shape, they are often tabular- planar/lenticular. The matrix content varies from section to section. This depends directly on the chert grains. When these grains prevail, the matrix content raises. Sometimes, despite the limestone clasts dominance, especially coarser ones, matrix content raises. But, the matrix in this unit is less compared to the grains (10-30\% in different horizons and sections). For this reason, we use the term clast-supported conglomerate for this facies. The matrix is of chert composition; its texture in the chert beds is clean, moderately-well sorted sandstone.

Stratification and gradation are usually absent, but a rough horizontal stratification and normal gradation are sometimes visible. The conglomerate is mostly disorganized in fabric, but a parallel fabric and imbricated structure can be recognized occasionally (Fig. 7). In some layers, coarsening upward is typical (Fig. 8A), but fining upward is also seen (Fig. 8B). 

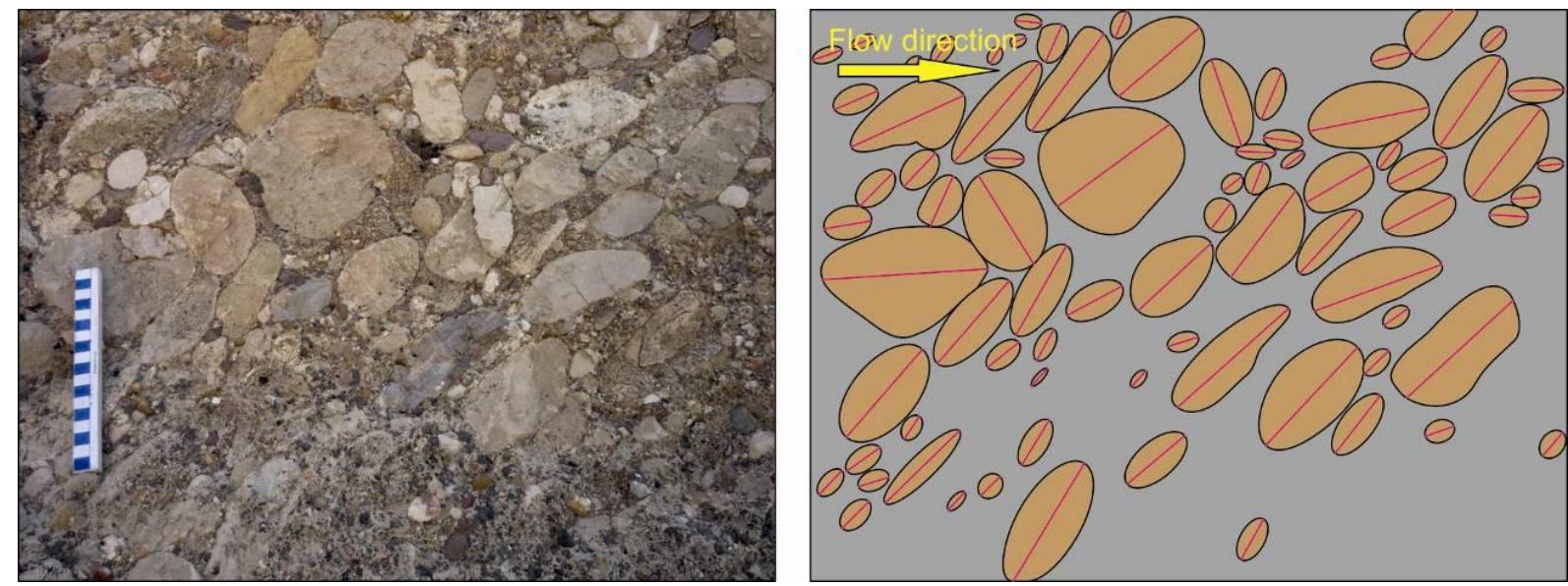

Fig. 7: Field and schematic photographs showing imbrication in the limestone-chert clast-supported conglomerate (LCCSC).
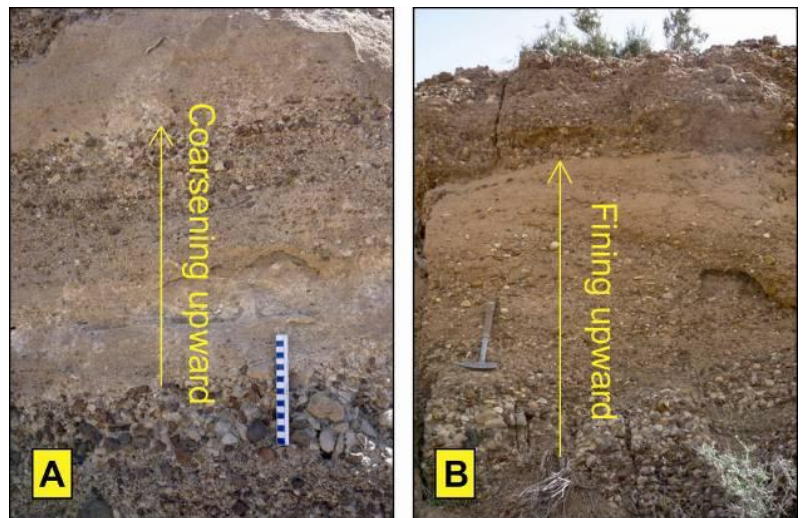

Fig. 8: A. Field photographs showing corsening upward and B. Fining upward in the LCCSC (limestone-chert clast-supported conglomerate).

The color of this lithostratigraphic unit depends on compositioning the clasts (limestone and chert). Since, compositioning the matrix is chert-supported, the prevailing color is reddish brown, i.e., the main color of the chert.

(b) Pebble-granule conglomerate (polymictic conglomerate) subfacies: This subfacies has a small extent, as compared with the previous one. Compositioning this conglomerate is similar to the boulder-cobble conglomerate, but its dominant composition is chert (65-80 \%) (Fig. 5); however, in some cases limestone clasts are prevail. Other clasts are of chert and, rarely sandstone. Main compositioning the matrix is chert, and the texture is moderately sorted, subangular-subrounded sand-sized grains.

The mean and maximum sizes of the chert clasts are in the range of pebble and cobble, respectively; while those of limestone clasts are of coarse-grained (pebble-cobble, and cobble-boulder). Other characteristics are as follows: massive, medium sorted, rounded to well rounded limestone clasts and subangular-subrounded chert clasts, and occasional rough stratification, but usually lacking internal structure.

\subsubsection{Sandstone facies}

Sandstone facies are seen in all sections of the LCCSC. This facies usually occurs as layers and lenses. From the view of textures, it can be divided into two subfacies. One subfacies consists of brown muddy sandstone, usually laminated and sometimes medium bedded. The maximum thickness of this unit is 0.8 meters and it extends 2.5 meters laterally (Fig. 9). The sandstone is coarse to very coarse-grained, and sparse granules and fine pebbles exist. This subfacies ends laterally with a sharp vertical edge or is wedge-shaped.

A second subfacies forms a cream to brown, coarse to very coarse-grained sandstone. Individual beds are planar, lentiform or wedge- shaped. Wedge- shaped units are centimeters thick, while planar beds are extensive and decimeters to meters thick, occurring as interlayers with conglomerate (Fig. 10). There are some cuttings or scours 50 centimeters deep filled in with micro- conglomerate. There are occasional small lenses of muddy micro- conglomerate a few centimeters thick. Lower and upper contacts of these deposits are sharp. 

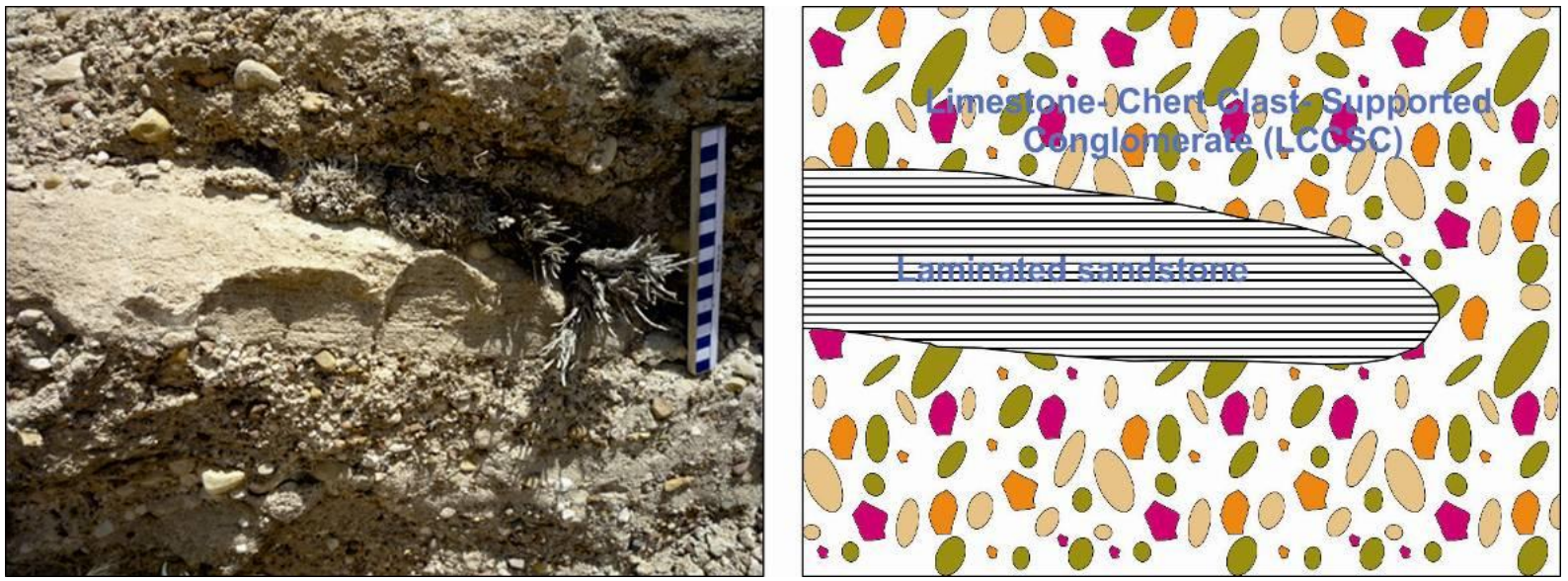

Fig. 9: Field and schematic photographs showing laminated sandstone in the limestone-chert clast-supported conglomerate (LCCSC).
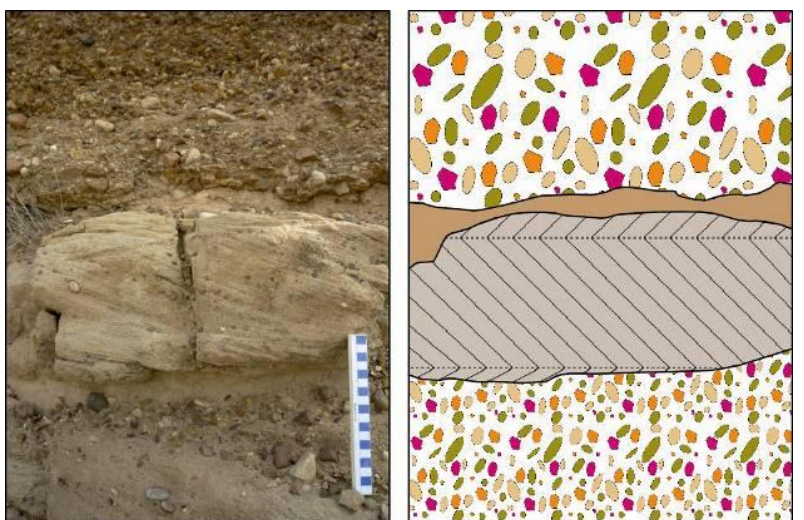

Fig. 10: Field and schematic photographs showing planar cross-beding with graded foresets in sandstone in the limestone-chert clast-supported conglomerate (LCCSC).

\subsubsection{Mudstone, siltstone and claystone facies}

In the upper part of this section, this facies consists of sandy mudstone to sandy siltstone with scattered grains of reddish chert granules and in the lower part of this section, this facies consists of muddy sandstone and sandy mudstones. There are laminae and thin lenses of reddish brown claystone up to 20 centimeters thick and spreading a few decimeters laterally. This is usually observed as thin laminated; the lower contact is transitional or sharp and the upper contact is sharp (Fig. 11).

\subsection{Limestone clast- supported conglomerates (LCSC)}

Two facies are recognized:

\subsubsection{Conglomerate facies}

This facies was observed in upper part of this section. This is a cobble-boulder conglomerate in the clasts are disorganized and closely packed together (clast-supported). The dominant clasts $(>90 \%)$ are of limestone composition. The clasts of chert form about 2- $20 \%$ of the unit. Other clasts are of polymictic conglomerate and sandstone (Fig. 12A). The mean sizes of the limestone and chert clasts are 20 and 2 centimeters, respectively, while the maximum sizes are 40 and 6 centimeters, respectively. Limestone clasts are usually of two main colors, light to dark cream and bluish gray.

The colors of the clasts are related on different formations. For example, the bluish gray clasts, which are characterized by Orbitolina microfossils, related on Cretaceous formations (i.e. Fahliyan Formation), while the light to dark cream coloured clasts are related on the Tertiary formations (i.e. Jahrum-Asmari Formation). Clasts are poorly to medium sorted and rounded to well rounded in outline. The matrix is dominantly of sand composition. Its texture is of clean coarse-grained sandstone. Its texture is of clean coarse-grained sandstone in some parts and muddy sandstone in other parts. Primary sedimentary structures and textural trends are absent. Clasts often coarsen upward. Individual beds are usually 3 meter thick or more and can be traced about 2-3 meters laterally. Some units consist of thinner beds but their 
thicknesses may reach meters. In vertical sections, lenses and layers of coarse-grained sandstone with different thicknesses and lateral extents exist in conglomerate units (Fig. 12B).
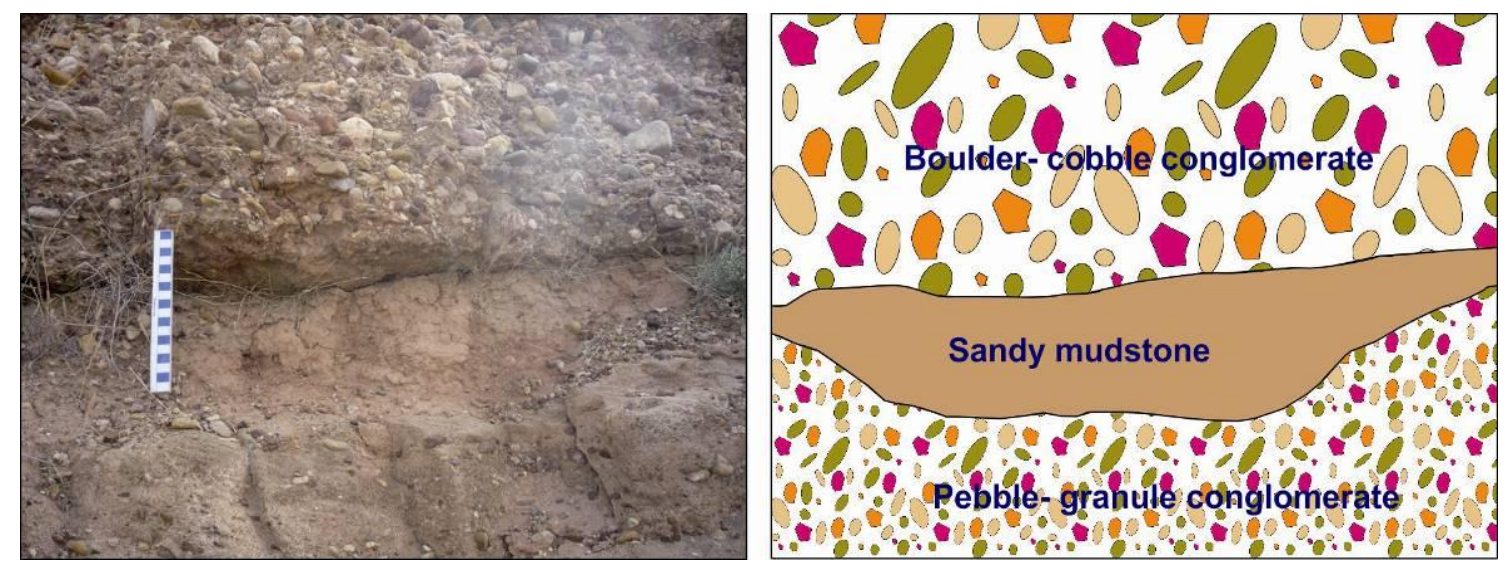

Fig. 11: Field and schematic photographs showing lens of sandy mudstone between boulder- cobble conglomerate and pebble-granule conglomerate.

\subsubsection{Sandstone facies}

Reddish brown to cream, medium- to coarse-grained sandstone with a dominant chert composition and various lateral extents forms in this facies (i.e. massive and horizontally bedding). Other characteristics are: medium-well sorted, subangular, and sparse granules and pebbles. Sandstone lenses about 20 centimeters thick have lateral extents of less than a few decimeters. Individual beds are planar, lenticular or wedge-shaped. These lentiforms and layers occur as small wedge-shaped units or planar beds a few decimeters thick. In relation on bedding thicknesses, two types of bedding are observed: thick to massive bedding and parallel thickly laminated to thin bedding.
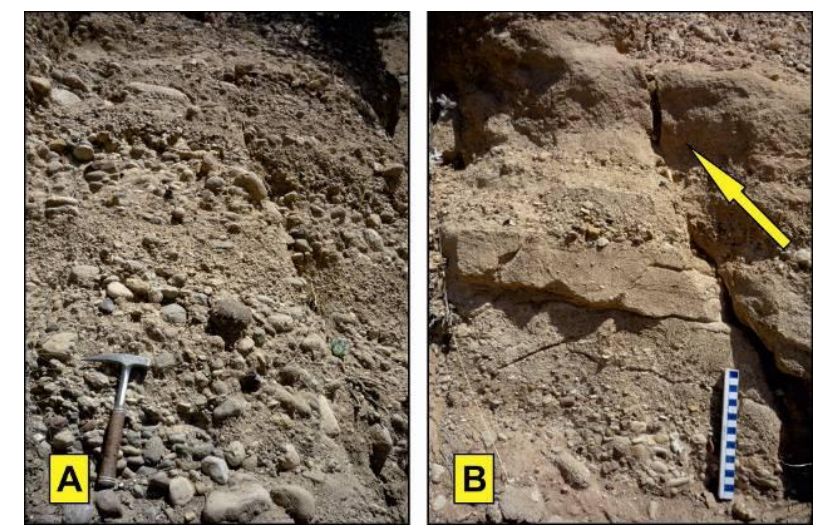

Fig. 12: A. Field photographs showing limestone clast-supported conglomerates (LCSC) and B. Lens of coarse-grained sandstone in conglomerate unit.

\section{Palaeogeography}

A shallow sea, which merged the region in the Paleogene, and occasionally underwent fluctuations caused by epirogenic movements, retrograded toward the south and southwest in Bourdigalian [4], and was replaced by set of continental environments such as lacustrine, fluvial and alluvial fans. These environments received sediments coming from erosion of previously uplifted regions. There is significant evidence for the gradual continuation and intensity of tectonic forces. These include a gradual decrease of chemical deposits in intracontinental shallow depressions and their mixing with detrital clays (formation of marl), creationing conditions that led to the formation of evaporates, such as gypsum and anhydrite (Razak Formation). The replacement of these deposits with fine- to medium-grained clastic sediments in the lower parts and coarse-grained in the upper parts (Aghajari Formation), a gradual coarsening upward of grain sizes (Bakhtyari Formation), and inter-formational angular unconformities, faults, folds and microstructures. The development of clastic sediments with a considerable horizontal (lateral) expanse and significant vertical continuation is closely related on the uplift of the Zagros Mountain Ranges. The Aghajari Formation is a formal formation in the Zagros Basin, which was influenced by the Alpine Orogeny. 
Clastic sediments at the Zagros stratigraphic sequence entered the region with the beginning of Alpine Orogenic movements, caused by the erosion of lands that previously cropped out in northern parts of the Zagros Basin [3]. In the Early Paleogene, a marine environment influenced the region and caused a thick carbonate to be deposited in its shallow parts, which were subsiding (Jahrum Formation). From the beginning of the Oligocene, orogenic movements in some parts of the Zagros Basin caused uplifting and folding of old beds in this region. These movements caused a meager stratigraphic hiatus at the top of the Jahrum Formation. This condition did not change the total shape of the Zagros trough [3].

Transgression of the Asmari Shallow Sea onto the Jahrum Formation caused a bed of polymictic conglomerate to be deposited (Fig. 4); in some locations, this transgression shows the Jahrum-Asmari Formation boundary. But, preservation of the total shape of the Zagros trough in the Oligocene caused the upper parts of the Asmari Formation to be deposited in shallow parts of the sea. In the Late Oligocene, orogenic movements intensified; the floor of the trough rose and the total trough was underlain by a shallow marine carbonate environment. This caused the rest of the Asmari Formation (Lower Miocene) to be deposited [16-17]. With the beginning of the Neogene, anticlines started to form about the Zagros Thrust to the southwest, leading to the retrogression of the Asmari Sea to the southwest. These folds and faults uplifted and eroded outcrops. Uplift of the Zagros highlands in the Early Miocene caused the uplifted formations to be exposed to erosion; the material was redeposited in the southern lowlands and depressions, forming the Middle Miocene Razak Formation. The lithofacies of the Razak Formation were deposited in a series of continental and subcontinental conditions like sabkhas and lagoons.

During the Upper Miocene, erosion of uplifted formations, especially Upper Cretaceous radiolarites (Radiolarian cherts; cropped out northwest of the study area, beyond the area in (Fig. 1) and Jahrum-Asmari Formations, intensified and the Aghajari Formation was deposited. Continued erosion of these formations, which were the products of uplift and migration of the Zagros highlands to southern regions, caused the Aghajari Formation sediments to migrate to the south and southeast. The lithofacies of the Aghajari Formation (mudstone, sandstone and conglomerate) were a variety of fluvial environments (meandering river channels, inter-channels and bars). In the Pliocene, with migrationing more folds to the southwest, uplift of the Aghajari Formation sedimentary environment and of formerly uplifted folds, meandering river systems (which flow on a steeper slopes) developed on the Aghajari Formation. LCCSC Lithofacies (Aghajari Formation) are the products of alluvial systems, mainly bedload streams. These lithofacies can be interpreted as channel lags [8-10, 18].

Horizontally stratified or unstratified conglomerates with clast imbrication record deposition on a flat bed with vigorous grain transport such as might occur on the top of a longitudinal bar or on a channel floor and textural variation may relate to water stage changes [19]. The scarcity of fines between episodic depositional structures may be caused by their removal by subsequent scour or to inherent lack of fines in the sediment supply. Upward fining may be related on either channel abandonment or the lateral accretion [20]. Upward coarsening in units of a few meters thick is attributed to gradual reactivationing a channel after an interval of temporary abandonment in the fluvial complex. At the larger scale, the grain size changes may be accompanied by changes in the relative abundance of constituent facies. Changes at this scale are commonly attributed to tectonic causes. Coarsening- and fining- upward sequences may result respectively from tectonic uplift of the source area or from their subsequent wearing down during a quiescent phase.

\section{Conclusion}

To simplify discussion, the following results are deduced from the view of sedimentology and palaeogeography of the study area:

- Two types of lithofacies are recognized in the conglomerates of the Aghajari Formation: LCCSC and LCSC.

- There are a series of thrust faults at the boundary of these lithofacies and this makes them each has its own independent chronological and spatial setting.

- Lithofacies form a reverse relief at least 1500 meters higher than plains.

- The clast parts of lithofacies belong to Tertiary and Cretaceous formations, cropped out near and far.

- The sedimentary environments of lithofacies are meandering rivers, which their deposition products are dominantly gravelly alluvium.

- Thick sequences of gravelly alluvium are generated and preserved where there is topographic relief and this commonly implies tectonic activity during or immediately before deposition. 


\section{Acknowledgements}

We thank Dr. S.H. Hejazi, A. Heydarieh, H. Heydari, M. Farajzadeh, and J. Maniani for their considerable helps throughout this study.

\section{References}

[1] James, G.A., Wynd, J.G., "Stratigraphic nomenclature of Iranian Oil Consortium Agreement Area", AAPG Bulletin, VOL 49, NO. 12, (1965), pp. 2182-245.

[2] Falcon, N.L., Southern Iran: Zagros Mountains. In: Spencer, A.M. (Ed.) Mesozoic-Cenozoic Orogenic Belts: Data for Orogenic Studies, Geological Society of London, Special Publication, VOL 4, (1974), pp. 199-211.

[3] Motiei, H., Geology of Iran, Stratigraphy of Zagros, Tehran, Geological Survey of Iran Publications, (1994), 538 p.

[4] Alavi, M., "Tectonics of the zagros orogenic belt of iran: new data and interpretations", Tectonophysics, VOL 229, NO. 3-4, (1994), pp. 21138.

[5] Alavi, M., "Structures of the Zagros fold-thrust belt in Iran", American Journal of Science, VOL 307, NO. 9, (2007), pp. 1064-95.

[6] Bahrami, M., "Sedimentology and morphotectonical evolution of Aghajari and Bakhtyari Formations in northwestern of Shiraz", Journal of sciences, Islamic Azad University, VOL 8, NO. 27-28, (1997), pp. 1995-2010.

[7] Bahrami, M., "Lithofacies and sedimentary environments of Aghajari Formation in Dehsheikh Mountain, west of Shiraz, Iran", World Applied Sciences Journal, VOL 6, NO. 4, (2009), pp. 464-73.

[8] Sahraeyan, M., Bahrami, M., "Fluvial cyclicity from Aghajari Formation (Upper Miocene- Pliocene) in Folded Zagros Zone, Southwestern Iran", International Journal of Advances in Earth Sciences, VOL 1, NO. 2, (2012), pp. 58-68.

[9] Sahraeyan, M., Bahrami, M., "Geochemistry of sandstones from the Aghajari Formation, Folded Zagros Zone, southwestern Iran: implication for paleoweathering condition, provenance, and tectonic setting", International Journal of Basic and Applied Sciences, VOL 1, NO. 4, (2012), pp. 390-407.

[10] Sahraeyan, M., Bahrami, M., "Petrography and provenance of sandstones from the Aghajari Formation, Folded Zagros Zone, southwestern Iran", International Journal of Basic and Applied Sciences VOL 1, NO. 3, (2012), pp. 283-98.

[11] Alavi, M., "Regional stratigraphy of the Zagros fold-thrust belt of Iran and its proforeland evolution", American Journal of Science, VOL 304, NO. 1, (2004), pp. 1-20.

[12] Mitchell, A.H.G., Reading, H.G., Sedimentation and tectonics. In: Reading, H.G. (Ed.) Sedimentary Environments and Facies, Blackwell, Oxford, (1986), pp. 471-519.

[13] Pollastro, R.M., Persits, F., Steinshouer, D., Map showing geology, oil and gas fields, and geological provinces of Iran. U.S. Geological Survey, (1999), Open-File Report 97-470G.

[14] Yousefi, T., 1/100000 map of Sarvestan, (2006), Tehran, Geological Survey of Iran Publications.

[15] Miall, A.D., The Geology of Fluvial Deposits, Sedimentary Facies, Basin Analysis and Petroleum Geology, New York, Springer-Verlag, (1996), $582 \mathrm{p}$

[16] Seyrafian, A., "Microfacies and depositional environments of the Asmari Formation, at Dehdez area (a correlation across central Zagros basin)", Carbonates Evaporites, VOL 15, NO. 2, (2000), pp. 121-129.

[17] Sahraeyan, M., Bahrami, M., Arzaghi, S., "Facies analysis and depositional environments of the Oligocene-Miocene Asmari Formation, Zagros Basin, Iran", Geoscience Frontiers, (2013), in press, doi: http://dx.doi.org/10.1016/j.gsf.2013.03.005.

[18] Collinson, J.D., Alluvial sediments. In: Reading, H.G. (Ed.) Sedimentary Environments and Facies, Blackwell, Oxford, (1986), pp. 20-62.

[19] Steel, R.J., Thompson, D.B., "Structures and textures in Triassic braided stream conglomerates ('Bunter' Pebble Beds) in the Sherwood Sandstone Group, North Staffordshire, England", Sedimentology, VOL 30, NO. 3, (1983), pp. 341-67.

[20] Ramos, A., Sopena, A., Gravel bars in low sinuosity streams (Permian and Triassic, Central Spain). In: Collinson, J.D., Lewin, J. (Eds.) Modern and Ancient Fluvial Systems, Special Publication, International Association of Sedimentologists, (1983), pp. 301-312. 